\title{
Energy Audit And Energy Conservation Potential For Water Treatment Plant
}

\author{
Budhsen Dubey ${ }^{1}$, Bhupandra Gupta ${ }^{2}$, Jaswant Singh pasricha ${ }^{3,}$ Mukesh Pandey ${ }^{4}$ \\ Student, Master of Engineering Jabalpur Engineering College, Jabalpur ${ }^{1}$ \\ Associate Prof.Govt.Engeenering College, Jabalpur ${ }^{2}$ \\ Certified Energy Auditor (BEE India), DGM, MP Power Trading Company (Electricity Department) Jabalpur \\ (M.P.) India \\ Professor and Dean Academics, UIT, RGPV, Bhopal India ${ }^{4}$
}

\begin{abstract}
This paper present energy audit process on water treatment plant located at Lalpur, Jabalpur Madhya Pradesh. This plant has established in 1986 and supplying 97 MLD (million liters per day) water to Jabalpur City. Generally Water treatment plants are highly energy and cost intensive. To achieve effective and efficient energy management scheme, energy audit analysis was employed on water treatment plant. This paper Provides customers with recommendations which will increase the comfort, health, safety and prolong the durability of the property. Before appointing Energy Auditor conduct our own visual walkthrough and make a list, so when we bring in an auditor we are prepared. Become more aware!, check savings calculations by determining whether more savings have been identified than are actually achievable. Some analysts use the average cost of electricity to calculate energy savings.
\end{abstract}

Keywords: - Water treatment plant, energy audit, energy saving, cost analysis, Overall Equipment Effectiveness.

\section{Introduction:}

Energy means is the capacity of a system to do work. We use energy to do work and make all movements, Energy can be found in a number of different forms. It can be chemical energy, electrical energy, heat (thermal energy), light (radiant energy), mechanical energy etc. The most general definition of an audit is an evaluation of a person, organization, system, process, project or product. Audits are performed to ascertain the validity and reliability of information, and provide an assessment of a system's internal control.

An energy audit was performed on the Water Treatment Plant (WTP) located at Gwarai Ghat Road Lalpur in Jabalpur. This report provides the energy use pattern, the measures considered and the recommendations for energy saving, more effective equipment use for water purification/water distributed to Jabalpur area. Water treatment plant has been highly energy and cost intensive. Continues running of the plant i.e. 8760 operating hours per year produce 35405 ML (million liters) water. To achieve effective and efficient energy management scheme, thermal energy audit analysis was employed on water treatment plant. The flow chart of water treatment process is as follows:-



Many types of equipment used just like a pump, motor, color, lighting, water etc. lalpur plant 97 MLD water supplies per day, these water taken from Narmada River. 3 hours cycle is required to purify water. The Water Flow from Jack Wall to Raw Water Pump House through gravity. 10 pumps (215h.p) are Establish in the pump house, however 6 Pumps are required $24 \mathrm{hr}$ running at a time \& 4 pumps are stand. Every 12hr Pumps are Change from another pump. Then with the help of 6 pump water flow to the $42 \mathrm{mld}$ and $55 \mathrm{mld}$ section. Water 
is purifying in these section. After that water is pumped by 6 pumps are established in $42 \mathrm{mld} \& 8$ pumps are established in 55 MLD.

\subsection{Conduct Auditing Process:}

- $\quad$ Study of plant process

- $\quad$ Meeting

- $\quad$ Energy Audit Team

- $\quad$ Plant Data Collection

- $\quad$ Field Investigation and observations

- $\quad$ Equipment Inventory and use

- $\quad$ Classification of Demand and Energy

- $\quad$ Develop ECMs and Implementation Strategies.

- $\quad$ Follow-Up

\section{Parameter which affects the energy audit for water treatment plant:}

- $\quad$ Raw Water quality

- $\quad$ Pumping

- $\quad$ Lighting

- $\quad$ Power factor

\subsection{Pumping Systems:}

11 pumps $(215,225,300 \mathrm{HP})$ are Running $24 \mathrm{hrs}$, at present the system power factor is about 0.93 . But after auditing PF will maintained nearly unity by establishing capacitor Bank. One of the most critical elements to improving water system efficiency is to optimize energy consumption by the pumping systems. Optimizing the system includes improvements such as matching the pump to requirements, optimizing the distribution piping, eliminating unnecessary valves, controlling pump speed where appropriate, and institutionalizing improved O\&M practices. Replace inefficient pumps with efficient. Install variable speed drives. Regular preventative inspection and maintenance, including cleaning or replacing impellers and checking lubrication of bearings. Trim impellers where pumps too large for the application but otherwise suitable. Create a system for regular monitoring of system components and performance. Install and maintain water meters; replace on a regular basis (about every 10 years). Develop metrics to track system performance and compare performance to appropriate benchmarks and targets. Monitor the pump system (such as valves, flow, pressure, rotating speed, energy used, volume pumped, and velocity in the main headers).

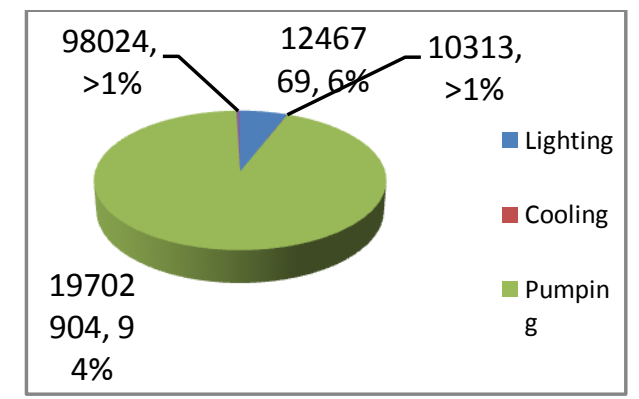

Figure 2:-.energy consumption chart



\subsection{Lighting:}

Figure 3:-: Pump House at Lalpur (Jabalpur) water treatment plant 
Light Level or luminance, is the total luminous flux incident on a surface per unit area. The work plane is where the most important tasks in the room or space are performed. In lalpur plant total $17 \mathrm{MU}$ electricity is being consumed per year. But after implementation of recommendation of energy auditing, electricity consumption will reduce by 15000 units per year. Apart from this about $153 \mathrm{kVA}$ demands will be reduced by installing a Capacity Bank.

\subsection{Transformer:}

There are six numbers of transformers $(33 \mathrm{KV})$ are installed in lalpur water treatment plant and three transformer are standby out of six transformer. Transformers are extremely efficient devices; however, since the entire power consumption of the plant is through the transformers, some loss does take place. Site testing of transformers is not possible without isolation of the transformers

Transformer efficiency $=\frac{\mathrm{KW}}{K W+\text { no load losses }+(\% \text { loading })^{2} \times \text { load losses }}$

\subsection{Water:}

Addition of alum and discharge of waste water from Flocculator should be regulated as per raw water quality. Fix water leaks. Test for underground water leaks. Check water overflow pipes for proper operating level. Provide proper tools for wash down especially self-closing nozzles. Eliminate continuous overflow at water tanks.

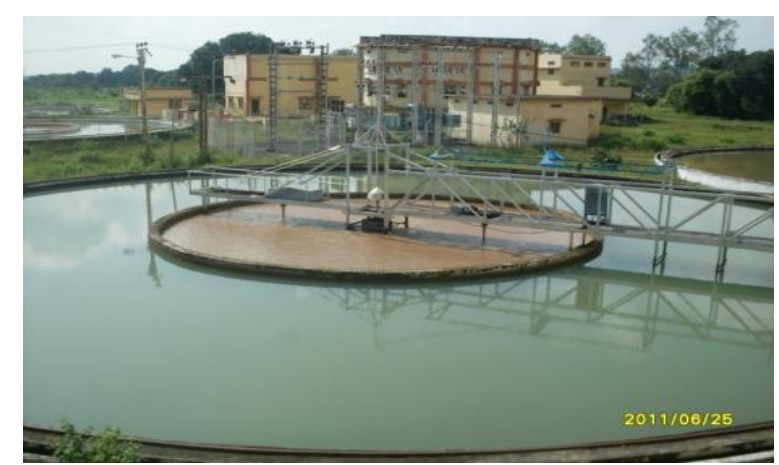

Figure 4:-Flocculator clarifiers at Lalpur (Jabalpur) water treatment plant

\subsection{Flocculator clarifiers:}

Effluent from the rapid mix structure flows by gravity to the flocculator clarifiers for the sedimentation process. The purpose of the flocculator clarifiers is to continue the flocculation process and produce clarified effluent, as well as to collect sludge and scum from the gravity settling basins. Specifically after the influent is mixed within the flocculator well. it migrates radically outward and enters the clarifier. Sufficient detention time is allowed to permit the solids to settle out in the clarifier during the time of flow to the outer ring of the clarifier. The effluent is removed at the tank periphery.

1. Tariff f category-2301 HV-5.133KV

III. Bill detail of lalpur water treatment plant

2. Monthly fixed charges-165 RS/ KVA (total maximum demand $\mathrm{x} 165$ )

3. $\quad$ Energy charges- 3.60 (Rs per unit) (consumption $\times 3.6$ )

4. $\quad$ Contract demand-2500 KVA

More energy consume in lalpur water treatment plant. Because overall plant power factor 0.93 hart show monthly consumption to one year. Average energy consumes per month $1400000 \mathrm{kWh}$.

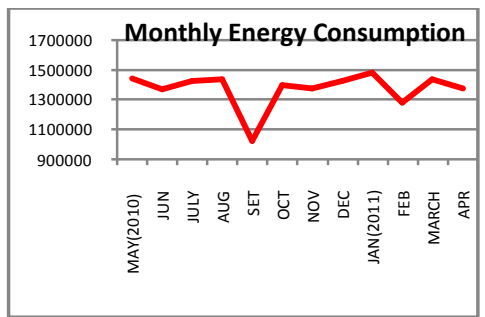

Figure 5:-overall unit consumption of lalpur water treatment plant. 


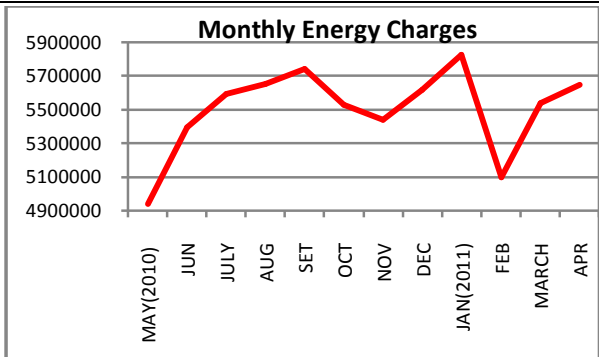

Figure 6:- annual bill detail o of lalpur water treatment plant (before auditing)



Figure7:Saving due to Installation of Capacitor Bank

\section{Recommendations:}

The main recommendation is to replace the recessed fluorescent lighting system in the general area and maintenance office.

- By Replacement of magnetic Ballast with electronics in existing tub light s i.e. 119 fittings having potential saving of $14700 \mathrm{kWh}$ that save $51750 \mathrm{Rs} /$ Year.

- Select ballasts and lamps carefully with high power factor and long-term efficiency in mind.

- Upgrade obsolete mercury lamp with Compact fluorescents with electronic ballasts Consider day lighting, skylights, etc

- Consider painting the walls a lighter color and using less lighting fixtures or lower wattages.

- Use task lighting and reduce background illumination.

For Water \& Wastewater:-

- Seal sumps to prevent seepage inward from necessitating extra sump pump operation

- Balance closed systems to minimize flows and reduce pump power requirements.

- Fix water leaks.

- Test for underground water leaks.

- Check water overflow pipes for proper operating level.

- Provide proper tools for wash down -- especially self-closing nozzles. 
- Eliminate continuous overflow at water tanks.

- Promptly repair leaking toilets and faucets.

- Use self-closing type faucets in laboratory.

Pump and motor:-

- Power factor improvement by installing capacitor bank which increase the power factor (0.99) and gives 153.38 KVA reductions in demand at a load of $2400 \mathrm{KVA}$ (Connected Load) that saves 39 lacks per annum.

- Properly size to the load for optimum efficiency. (High efficiency motors offer of 4 - 5\% higher efficiency than standard motors)

- Balance the three-phase power supply. (An imbalanced voltage can reduce $3-5 \%$ in motor input power)

- Repair seals and packing to minimize water waste.

- Balance the system to minimize flows and reduce pump power requirements.

\section{Results:}



\section{Conclusion:}

From this paper, we have concluded, An Energy audit increases the productivity of Organization. Energy audit helps to increase output of any industry and decreases cost of Production without scarifying the efficiency. Energy audit provides batter stability to the industry or organization then the statutory audits. With the help of above observations table it is found that Lalpur Water Treatment Plant needed to improve its efficiency in terms 
of pumping power, transformer's function, and lighting. Energy audit is done to improve its pumping power and lighting power for improving overall performance of Lalpur water treatment power plant. During energy audit it is found that 25 halogen light of 250 watt , used, electricity bill of last on year 66019849 Rs.kr calculated finally it is concluded that electricity bill will reduced $14733 \mathrm{kwh}$ by the audit.

[1] Bureau of Energy Efficiency hand book.

\section{References}

[2] Gallaher KP. Free trade and the environment: Mexico, NAFTA, and Beyond. Stanford University Press; 2004. p. 125.

[3] OECD. Environmental performance review of Mexico. OECD; 1998.

[4] Mumme S. Environmental politics and policy in Mexico. Ecological policy and politics in developing countries. State University of New York Press; 1998

[5] Carmona-Lara MdC. Ley General delEquilibrioEcologicoylaProtección al Ambiente: Comentarios y Concordancias. 1st ed. UniversidadNacionalAutónoma de México; 2003. p. 773.

[6] Greely K., Harris J., and Hatcher A., Measured Saving and Cost- Effectiveness of Conservation Retrofits in Commercial Buildings, Lawrence Berkely National Laboratory Report-27586, Berkeley, CA, 1990

[7] Fels, J., Special Issue Devoted to Measuring Energy Savings: The Socrekeeping Approach, Energy and Buildings.

[8] Thumann, A., and Mehta, P., Handbook of Energy Engineering. The Fairmont Press Inc., Librun, GA 1997

[9] Tuluca A., and Steven Winter Associates, Energy Efficient Design and Constructionfor Commercial Buildings, Mc-Graw Hills, 1997.

[10] MoncefKrarti, Energy Audit of Building system- An Engineering Approach.., CRC Press LLC 2000.

[11] Dasgupta S, Hettige H, Wheeler D. What improves environmental compliance? Evidence from Mexican industry. Journal of Environmental Economics and Management 2000; 39(1):39e66.

[12] Camper, A. K., LeChevallier, M. W., Broadway, S. C. and McFeters, G. A.(1985) Growth and persistence of pathogens on granular activated carbonfilters. Applied and Environmental Microbiology, 50(6), 1378-1382.

[13] Camper, A. K., LeChevallier, M. W., Broadway, S. C. and McFeters, G. A.(1986) Bacteria associated with granular activated carbon particles in drinkingwater. Applied and Environmental Microbiology, 52(3), 434-438.

[14] Carlson G and Silverstein J (1997) Effect of ozonation on sorption of naturalorganic matter by biofilm. Water Research 31, 10, 2467-2478

[15] Carlson KH and Amy GL (2001) Ozone and biofiltration for multipleobjectives. Journ. AWWA 93:1, 88-98.

[16] Carlson, K. H. and Amy, G. L. (1998) BOM removal during biofiltration.Journal AWWA, 90(12), $42-52$.

[17] G. R. Davis, "Energy for planet earth,"Scientific American, pp. 1-10,1991.

[18] U.S. Department of Commerce,Statistical Abstract of the UnitedStates,114th ed., 1998.

[19] S. Rahman and A. D. Castro, "Environmental impacts of electricitygeneration: A global perspective," IEEETrans. Energy Conv., vol. 10

[20] Energy efficient lighting CEA,2004 